\title{
Estimation of Innovative Business Processes of the Enterprises in Conditions of Emergence Economics
}

\author{
Mykhaylo Voynarenko \\ First Vice-Rector, Vice-Rector for \\ Scientific-Pedagogical \\ and Scientific work \\ Khmelnytsky National University \\ Khmelnytsky, Ukraine \\ voynarenko@ukr.net \\ http://orcid.org/0000-0002-1301-1492 \\ Olena Menchynska \\ Department of Economics and \\ International Relations \\ Vinnytsia Trade and Economic \\ Institute of KNTEU \\ Vinnytsia, Ukraine \\ derkacholena@ukr.net \\ http://orcid.org/0000-0002-1549-4870
}

\author{
Zakharii Varnalii \\ Department of Finance, \\ Taras Shevchenko National University \\ of Kyiv \\ Kyiv, Ukraine \\ vzs1955@gmail.com \\ http://orcid.org/0000-0002-6654-8760
}

\author{
Viktoriya Hurochkina \\ Department of Enterprise \\ Economics \\ University of the State Fiscal Service \\ of Ukraine \\ Irpin, Ukraine \\ viktoriav2005@ukr.net \\ http://orcid.org/0000-0001-8869-0189
}

\begin{abstract}
Under the terms of the manifestations of characteristics emergent economy in Ukraine, is gradually strengthening its influence on the functioning of the industrial enterprises, which require significant concentration of efforts on innovation development. The modern state of functioning of industrial enterprises in the world economy is characterized by the presence of a significant number of global value chains, which form a cluster of associations, corporations, conglomerates, holding companies, consortia, increasing the dependence of national economies on imported raw and materials. So, actualized need to develop conceptual scheme of economic diagnostics, which is focused on determining the effect of the introduction of innovative business processes and manage the development of integrated value chains for the purpose of clustering of industrial enterprises. In article is submitted the new conceptual scheme of estimation of innovative business processes of the industrial enterprises in conditions emergence economies which unlike existing defines the sequence of estimation of impact of innovative business processes on management of their development, and provides a combination of integrated estimation the level of introduction of innovative business processes, economic-mathematical modeling of influence of production factors on profitability of the enterprise for the purpose of definition like its economic growth and for the further choice of strategy of response to corresponding changes in emergence to economy.
\end{abstract}

Keywords - innovative business processes, value chain, scheme, analysis, evaluation, model, modeling, forecasting

\section{INTRODUCTION}

In world economic systems external impact of global changes is observed considerable, they change course events both external and internal environment of functioning industrial enterprises countries of the world. Therefore, for strengthening it is competitive abilities national economies in general and industrial enterprises in particular, in the center of attention innovation as a product, innovative business processes and reconsideration all technologies borrow. For purpose achievement the most useful effect of introduction innovative business processes economic diagnostics and accurate estimations and realization innovative business processes at each stage of accumulation and creation added value in the integrated chains emergence economies is extremely important. At the heart of methodology conceptual scheme of economic diagnostics of innovative business processes in integrated cost chains conditions an emerging economy are a set methods and techniques, integral, taxonomic evaluation, economic-mathematical, simulation modeling and forecasting.

Scientific and methodical approaches to estimation innovative business processes of the industrial enterprises for conditions emergence economies demand new conceptual changes which first, contain all necessary criteria for selection mechanisms of adaptation innovative business processes to emergence changes in economy, secondly, the costs based on value-oriented approach for maximizing and accumulation value at each stage of analytical estimation.

The result of developing a conceptual diagram of economic diagnostics of innovative business processes in terms of integrated value chains is to identify the achieved level of economic development for clustering purposes. This will facilitate successful decision-making.

\section{LITERATURE REVIEW}

Foreign and domestic scientists investigated different approaches to estimation of business processes within already created clusters, focusing attention on influence of factors external and internal environments that inherent emergence to economy of Ukraine.

In work Fasse Anja C., Grote Ulrike \& Winter Etti [1] is a theoretical basis of estimation and implementation economic-mathematical modeling during estimation of an innovative component business processes. Authors in the work "Recent developments in applying environmental value chain analysis" allocate an innovative component when functioning a chain added value. They analyzed interconnection between the innovative strategy and efficiency of introduction innovations (in it is production and sales chains provision services) that is carried out on the 
example of Malaysian telecommunications' industry. By results of their research it was revealed that generation of the ideas and their distribution and introduction significantly influence the innovative strategy an enterprise, at the same time Innovative strategy has positive influence on development services and their advance.

Rojers $\mathrm{P}$ Joseph in the of the work "Digital Transformation, Business Model Innovation and Efficiency in Content Industries" proves that digitalization and digital networks can save expenses which are inherent in a cost chain in content industry. This transformation creates new values in several points of a chain of cost that leads to emergence of new business processes that increase income of the enterprise by involvement of new clients or encouragement of the existing clients to consumption [2].

Set of methods in estimation efficiency and functioning of economic systems in economic literature, according to L. M. Blahodyr, divide into two groups. Methods calculations of coefficients enter into the first group (a method discounted a cash flow, a method of capitalization income, a payback period method, calculation a point profitability of the project). Methods at the second group are based on application econometric approach [3]. Econometric approach is based on a concept marginal efficiency, counted taking into account the separate enterprise coming values of indicators to potential or the actual limit of efficiency which is calculated on the basis production function [4].

Today the production function takes place in different dir ections of economic research. For example, Azam, M., and K han Abdul used Cobb-Douglas production functions to analyze long-term prospects for Malaysian economy, Among determinants, capital was also recognized as a deter minant [5]. Principles of the formation of production functions aimed at analysis of efficiency production, supplements the most important factors and relationship factors of production, which gives grounds for application in new conceptual approach to evaluation of innovative business processes in business structures.

In works A. Mapanga et.al "Barriers to effective value chain management in developing countries: new insights from the cotton industrial value chain"'[6] and B. Penny et.al "Connecting Local Producers in Developing Countries to Regional and Global Value Chains" [7] considerable attention is paid to research of various approaches to assessment business processes within global chains cost of enterprise structures. It is necessary to distinguish work E.V. Krikavsky's and Z. Patora Vysotskaya from the domestic authors who were engaged in development this perspective "A chain cost of Porter (design, deconstruction, reconstruction) and managements behind values", in it authors placed emphasis on importance of value-oriented approach to assessment business processes in a chain cost [8].

A. Asaul, M. Voynarenko, L. Dzhulii et.al disclosed essence of the latest information systems, their influence on development and features management business processes of the industrial enterprises. They proposed model, wich takes the first stage of elaboration and has a theoreticalmethodological character. In authors idea the model of company's economic activity context implementation implies the 4th stages [9].
Reasonably the choice a strategic position development of the enterprises that is provided with the concept formation of a context economic activity company in emergence conditions M. Voynarenko, K. Dumanska and N. Ponomaryova. By authors it is also developed analyticalcalculating aspects testing and their further realization in strategic practice management of industrial enterprises [11].

The system analytical tools of the integrated administrative analysis is developed for strategy of activation innovative development enterprise L.M. Karpenko, S. V. Filyppova, P. V. Voronzhak [12], [13]. The system of analytical tools of integrated managerial analysis for the activation strategy of the enterprise innovative investment development the system. A. A. Melekhov found connection between integrated coefficient of innovative activity and gross revenues, having proved that due to improvement factors production and increase in innovative activity enterprises of mechanical engineering in Ukraine it is possible to raise gross revenue studied enterprises of industry. However, it is necessary to mark out about defined incompleteness scientific developments the author on use results modeling of productions when forming cluster about connections and use practical mechanism's introduction of innovations in activity enterprises of mechanical engineering [14].

In modern conditions the importance of innovative activity for ensuring achievement and development enterprises in conditions of new economy on principles sustainable development amplified. In this context is relevant researches M. V. Dykha, N. P.Tanasiienko, G. M. Kolisnyk, within whom scientists proved priorities of structurally innovative reorganization economy and also allocated the direction's development of venture business and stimulation of production hi-tech, it is competitive products [15].

Also, the work Iryna Strutynska, Galina Kozbur, deserves attention, Lesia Dmytrotsa, Olena Sorokivska, Liliya Melnyk, especially considering attention paid in it to a digitalization and automation of innovative business processes that is extremely necessary in conditions emergence economies. In particular, use modern technologies, innovative products can become a basis their introduction [16]. Developments systemically of the integrated methodical approach to estimation level achievement of sustainable development the industrial enterprises on the basis of business indicators it is presented in work L.M. Melnik [18], where the author allocated four consecutive stages of estimation on effective use of business indicators.

L. V. Vaganova, I. I. Chaikovska, N. A. Khrushch, P. M. Hryhoruk in their scientific work investigated general concepts with network structures, substantiated interconnection of functioning essential characteristics an phenomenon network economy; have emphasized management network structures based on use of an arsenal methodological approaches to the assessment of their internal processes in terms of financial component [19]

Purpose scientific work «Factors of enterprises' strategic selection of participation forms in integration formations» $\mathrm{V}$. Stadnyk, P. Izhevskiy, O. Zamazii, A. Goncharuk, O. Melnichuk is allocation of the main motives economic behavior enterprise units in Ukraine causing structural 
changes in industrial sector and agrarian and industrial complex and developments an algorithm justification of the strategic choice by the enterprises forms participation in integration educations for realization of competitive strategy and development of business [20]. This research valuable also in terms of publicizing value-oriented approach to estimation business processes in network structures on the basis vertical integration which is inherent in a sector agroindustrial of the emerging economy.

The Ukrainian scholars Olena Palyvoda, Oksana Karpenko, Olena Bondarenko, Svitlana Bonyar and Andrea Bikfalvi, investigating process of creation of correlation regression model of dependence of the innovative index of light industry and a share of the innovation-active enterprises participating in global networks of innovative partnership or have network cooperation with foreign partners from EU countries, proved interconnection between innovative activity and versions network interactions for effective strategic management of network structures [20].

Taking into account significant contribution of foreign and domestic scientists, it is expedient to improve system of assessing impact of environmental factors and consider preconditions for favorable formation of networks and circuits in the emerging economies.

\section{CONCEPTUAL SCHEME AND MAIN STAGeS OF ECONOMIC DIAGNOSIS OF INNOVATION BUSINESS PROCESSES}

Under conditions when globalization changes and transformations have a significant impact on the external and internal environment of the functioning of industrial enterprises from different countries of the world, only in the smallest part of them, qualitative characteristics of these changes are manifested. The largest impact is on production networks and integrated cost chains, as they today dominate the global economy and are a powerful force in international industrial and business relations between industrial enterprises from different countries of the world. Such qualitative characteristics of the system's change are called the properties of integrity or endangered properties. The economic nature of the emergent properties of the economic system is based on the management of knowledge and information, which ultimately accelerates the movement of innovation, economic or innovative development takes place, and a high standard of living is achieved. The introduction of innovations and innovative business processes must be effective, and hence controlled at each stage of the accumulation and creation of added value in integrated circuits. To this end, it is crucial to respond in a timely manner to changes through an analytical assessment of the implementation of innovations and innovative business processes. The conceptual scheme of economic diagnostics, developed by the authors, focused on determining the impact of innovative business processes and on the development of management of integrated cost chains for clustering purposes, is presented in Fig.1. Using a value-oriented approach with analytical assessment, we detail the stages of the conceptual scheme of economic diagnostics of innovative business processes in integrated cost chains in the conditions of an emerging economy.

Stage I. Finding among the largest strategic partnerships, groups of enterprises that create value chains with the best returns.
Such search, in our opinion, should be carried out in absolute terms (asset volume, net income from sales of products, goods and services (revenue)) and relative (return on assets, working capital, net margin, interest in total assets, coverage ratio). Added value is the basis of financial management. These key indicators allow us to select leaders from all businesses.

Stage II. Calculation of economic effect, profitability and integral level of implementation of innovative business processes.

An integral part of the value chain is the transfer of innovation and innovative business processes that form the innovative potential of any enterprise. But the result of the implementation of innovative business processes is undoubtedly the creation of added value, which is the center of economic efficiency of any activity.

The size of the creation of value added is characterized by profits of business entities. Therefore, each integrated cost chain enterprise tries to provide optimum conditions for the formation of the maximum possible value added.

According to the concept of economic profit (residual, economic income) the company creates value for shareholders only when it receives economic profit. The main indicator, according to this methodology, is the value added index. The added value is calculated as the difference between the production (revenue) of products or services provided as a result of production activity and the intermediate consumption of production of materials, raw materials, accumulation of depreciation (since the company's core assets are involved in the creation of value) additional products) and other operating expenses. The added value may still be determined by production costs, when the gross operating income is adjusted for subsidies and indirect taxes.

The calculation of value added is based on the formula:

$$
V A=R-M E-D-E o,
$$

where $R$ - revenue from sales; $M E$ - material expenses; D - depreciation; $E_{o}$ - other operating expenses;

One of the main economic indicators are the indicators of economic added value of the enterprise.

The basis of the model of economic value added (EVA economic value added) is the concept of residual income. Economic Value Added (EVA) is the company`s profit from ordinary activities, net of taxes, reduced by the amount of payment for all capital invested in the company, and is calculated by the formula:

$$
E V A=N O P A T-W A C C \cdot I C,
$$

where NOPAT is net operating profits after taxes; WACC - weighted average cost of capital; $I C$ - invested capital.

Today EVA is seen as an innovative methodology for calculating the value of an enterprise, given its economic development. EVA acts as an indicator of the quality of management decisions at the enterprise, because it characterizes the value of the enterprise. The optional EVA value represents an increase in value, and the negative one is a reduction in the value of an enterprise. The added value of EVA is an indicator of the quality of management decisions. Its positive significance characterizes the efficient use of 
capital and indicates an increase in the value of the enterprise; In this case, the EVA value is zero, this characterizes a certain kind of achievement, since the owners of capital actually received a rate of return that compensates for the risk; the negative value of EVA characterizes the inefficient use of capital and indicates a reduction in the value of the enterprise and its investment unattractiveness.

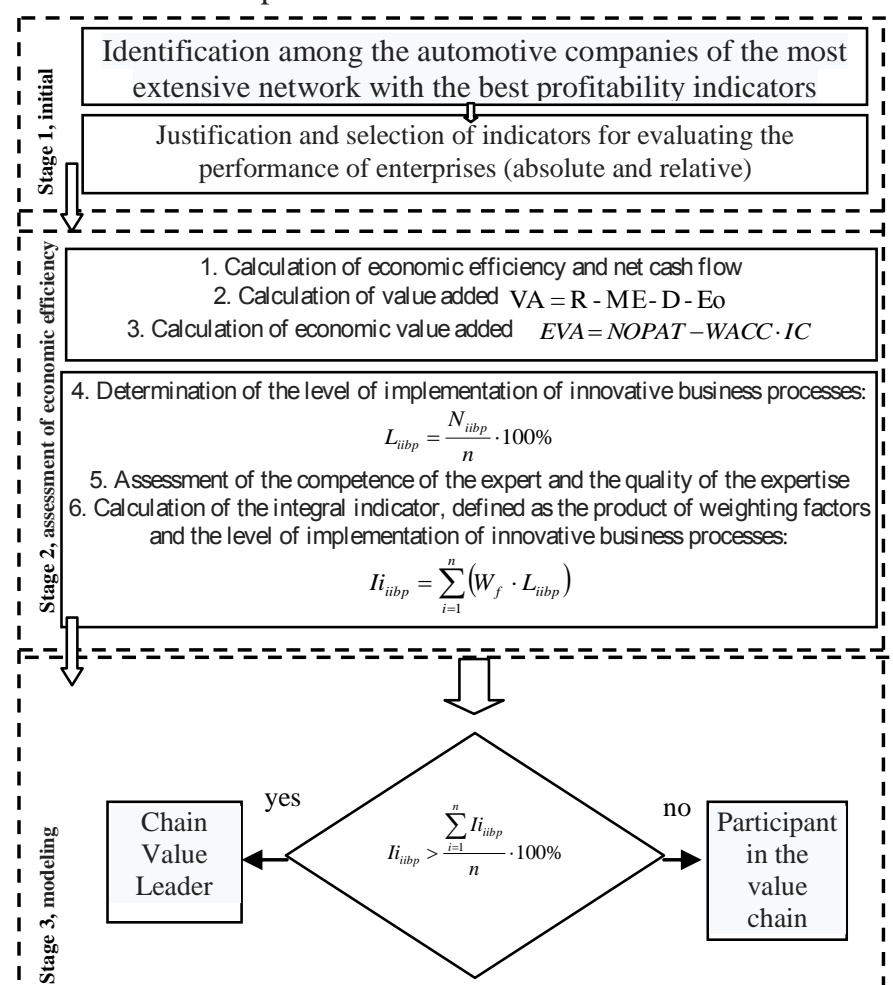

Construction of a two-factor model of the dependence of production volume on the 1 resources used (for each business chain) $Y=p L^{a} K^{b}$

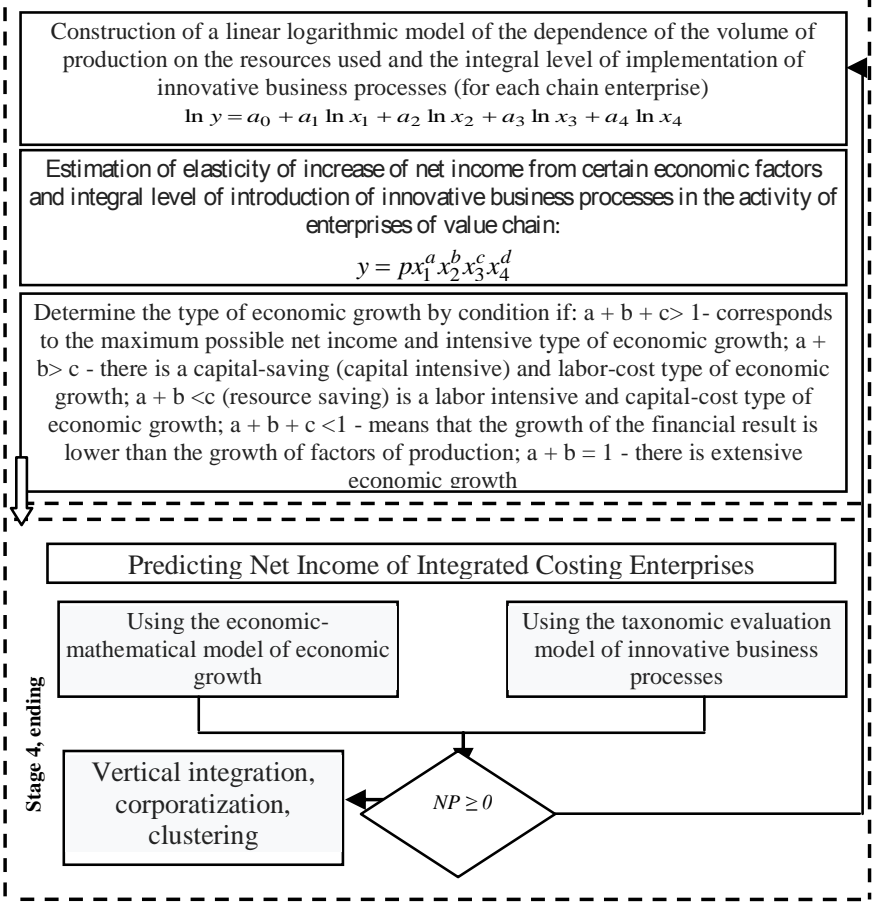

Fig. 1. Conceptual scheme of economic diagnostics, focused on determining the impact of innovative business processes on the development of management integrated cost chains for clustering purposes.
The results of the survey are based on the generalization of the ranking of respondents to the importance of promising directions of integration of innovative business processes in the integrated value chain. To determine the level of implementation of innovative business processes, use the following formula:

$$
L_{\text {iibp }}=\frac{N_{\text {ibp }}}{n} \cdot 100 \% \text {, }
$$

where $L_{i i b p}$ - the level of implemented innovative business processes, $\% ; N_{i i b p}$ - the number of innovative business processes implemented at the enterprise; $\mathrm{n}$ - the total number of innovative business processes proposed for implementation at the enterprises of the value chain.

In order to achieve accurate results when evaluating each object, it is expedient to use a group expert assessment, which is determined by summing individual ratings on the scale of competence. The rating of the competence of the evaluation is equal to the expert's coefficient of competence. In this case, it is necessary to calculate the coefficients of competence for each expert. The essence of this method of calculation is based on assumptions about the competence of experts and is evaluated according to the level of consistency of marks of signs with the corresponding group estimation. The expert's coefficient of competence evaluation is carried out according to the formula:

$$
K_{j}=\frac{\sum_{i=1}^{n}\left(x_{i j} \cdot m_{i}\right)}{\sum_{i=1}^{n}\left(m_{i} \cdot s_{i}\right)}
$$

where $K_{j}$ - coefficient of competence $j$-th expert; $x_{i j}$ estimation of the $i$-th object exposed by the $j$-th expert; $m_{i}$ the average score of the $i$-th object; $s_{i}$ is the sum of estimates for the $i$-th object.

The quality of the expert examination is evaluated using the coefficient of concordance $W$ (consensus of expert opinions) and is calculated by the following formula:

$$
W=\frac{12 \cdot S}{n^{2} \cdot\left(m^{3}-m\right)},
$$

where $S$ - is the sum of the squares of the deviations of the sum of estimates of each object from their average; $n$ number of experts; $m$ - the number of innovative business processes (objects of evaluation).

The coefficient of concordance varies in the range from 0 to 1 , at the value of 0 the indicator characterizes the complete inconsistency, with 1 - characteristic of complete unanimity. The coefficient of concordance is taken into account in determining the weighting factor of the innovation business process. Calculation of the integral index, defined as the product of weighting factors and the level of implementation of innovative business processes:

$$
I i_{i b p}=\sum_{i=1}^{n}\left(W_{f} \cdot L_{i b b_{p}}\right),
$$

where $I i_{\text {sicn }}$ - is the integral index of implementation of innovative business processes in the value chain, $\% ; W_{f}$ - the weight factor (taking into account the coefficient of concordance).

The indicators of the implementation of business processes by types of business processes or by the vectors of innovative development and types of economic activity of the investigated industrial enterprises look very informatively. It allows to focus attention of managerial 
decisions on key areas of development and to respond in a timely manner to the manifestations of the emergence of the economy.

Stage III. Economic-mathematical modeling of the influence of innovative business processes on the development of enterprises of the integrated circuit. Priorities in assessing the level of influence on the implementation of innovative business processes in the integrated value chain are that industrial enterprises use economic and mathematical modeling. In our opinion, in economic-mathematical modeling, the integrated chain of cargo industrial enterprises is a key place in the production function, that is, how it reflects the production process.

The production function of C. Cobb and P. Douglas is a two-factor model of production of the used resources:

$$
Y=p L^{a} K^{b}
$$

where $Y$ - volume of manufactured products; $L$ - labor costs; $K$ - volume of functioning fixed assets; $p, a, b$ parameters of the production function.

Logarithm for both parts of equality

$$
y=e^{a_{0}} x_{1}{ }^{a_{1}} x_{2}{ }^{a_{2}} x_{3}{ }^{a_{3}},
$$

We can get the following:

$$
\ln y=a_{0}+a_{1} \ln x_{1}+a_{2} \ln x_{2}+a_{3} \ln x_{3}+a_{4} \ln x_{4},
$$

where $-x_{1}$ the cost of labor resources (the number of production personnel or the cost of working time); $x_{2}$ - cost of industrial and production fixed assets; $x_{3}$ - the cost of working capital. Given the level of implementation of innovative business processes to determine its relevance for clustering purposes, the production function will have the following form: where $-x_{4}^{(i)}$ the integral level of implementation of innovative business processes in the enterprise.

The constructed model of production function, taking into account the integrated level of implementation of innovative business processes, will allow us to estimate the elasticity of increasing net income depending on the factors of influence (the number of employees at the enterprise, the cost of the main and the turnover, enterprise assets and integral level of implementation of innovative business processes).

Stage IV. Predicting Net Income of Integrated Costing Enterprises

As a result of the construction of the model, the forecast of net profitability of enterprises, the integrated cargo turnover chain provides for the continuous introduction of innovative business processes, which allows determining the direction of long-term development of industrial enterprises. As it extends the possibilities of determining the maximization of financial performance and focuses on ensuring stability and the fulfillment of the conditions of uninterrupted activity at each stage of the integrated value chain. According to the results of construction of the production function taking into account the integrated level of implementation of innovative business processes of industrial enterprises that are part of the value chain, it is possible to determine the type of economic growth of each enterprise according to the above conditions on the following condition: $a+b+c>1$ - corresponds to the maximum possible net income and intensive type of economic growth; $a+b>c-$ there is a capital-saving (capital intensive) and labor-cost type of economic growth; $a+b<c$ (resource saving) is a labor intensive and capital-cost type of economic growth; $a+b+c<1$ - means that the growth of the financial result is lower than the growth of factors of production; $a+b$ $=1$ - there is extensive economic growth. Using the results of forecasting when making managerial decisions, it is advisable to focus on the optimal values of resource support for all processes. It is also strategically important to ensure the stability of the functioning of the cluster consolidation of enterprises and the implementation of conditions for uninterrupted economic activity at each specific stage of the value chain.

The taxonomic integral model for estimating the group of innovative business processes based on the development vector is based on the definition of the integral index of taxonomic indicators, which can be represented as:

$$
\boldsymbol{I}_{i v d}=\sqrt[m]{\prod_{i=1}^{m} \boldsymbol{I}_{t}}
$$

Where $I_{i v d}$ - is the integral index of the vector of development ( $\mathrm{i}=$ from 1 to $\mathrm{n}) ; I_{t}$ - taxonomic index of the vector of development ( $\mathrm{i}=$ from 1 to $\mathrm{m})$.

The taxonomic index of the development vector is calculated as a function of the set of expert estimates on the indicators of the development vector.

$$
I_{t}=f\left(P_{i m t i}, P_{c p t i}, P_{p i i}, P_{c s v a i}\right),
$$

where $P_{\text {imti }}$ - component of the importance of the th taxonomic index of the vector of development; $P_{c p t i}{ }^{-}$component of the potential of the i'th taxonomic index of the vector of development; $P_{p i i}$ - a component of the possibility of introducing innovation for a given period of time; $P_{\text {csvai }}$ - component stimulation (distillation) of the value added node innovation.

Indicator is determined by 1 ( 0 is the lowest level, 1 is the largest). The obtained data are the basis for forming the level of comparison of the criteria that can be evaluated by the generalized indicator Pi based on four complex variables for each of the directions of development: the level of importance (significance); level of realization of the potential; forecasted indicators of lowering costs or increasing revenues (depending on the features of the innovation node) - stimulating / disabling activities; the level of opportunities for introducing innovations for the period of strategic planning. Thus, the obtained results make it possible to determine which indicators have the greatest value of development, and which are the least, and allow to estimate the level of payback of innovative processes and their influence on the result of the activity of the chain. In our opinion, based on the results of the taxonomic integrated estimation model, it is advisable to construct a model of the national rum (key competitive advantages, factors of influence, demand conditions, intermediate and auxiliary industries) and an imitative model of the potential core of the cluster in order to form potential clusters around key sectors of the national economy. Such steps allow us to focus on the formation of a strategy for the further development of cluster education. 


\section{CONCLUSIONS}

The authors suggest a conceptual scheme of economic diagnostics focused on determining the impact of innovative business processes on the development of integrated management cost chains for clustering purposes. Such an algorithmic approach to the assessment involves a combination of integrated assessment of the level of implementation of business processes, economic and mathematical modeling of the influence of production factors and prediction of profitability in order to determine the type of economic growth of the value chain. Such an approach to assessing innovative business processes in the cost chain management system enables the formation of an integrated cost chain structure based on integration vectors, identifying innovative business processes and the sequence of their implementation, such as economic growth and the feasibility of clustering. The resulting calculations provide an opportunity to make a reasonable choice of innovation development strategy in integrated cost chains and build a model of interaction between suppliers, manufacturers, distributors and dealers.

\section{ACKNOWLEDGMENT}

The work was carried out within the framework of the state budget scientific research topic number 7B-2016 "Models and technologies of cluster formation in the strategies of institutional development of socio-economic systems" (2016-2018 years), for financing the Ministry of Education and Science of Ukraine (state registration number 0116U001551).

\section{REFERENCES}

[1] A. C. Fasse, U. Grote \& E. Winter, "Recent developments in applying environmental value chain analysis", Environmental Economics, vol 2(3), 2011. [Online]. Available: https://www.researchgate.net /publication/216173671 Accessed on: July 8, 2019.

[2] J. P. Rojers "Digital Transformation, Business Model Innovation and Efficiency in Content Industries: A Review", The International Technology Management Review, vol. 7, no. 1, pp. 59-70, 2018.

[3] L. M. Blahodyr, "Metodychni zasady otsiniuvannia efektyvnosti funktsionuvannia pidpryiemstva iz vykorystanniam vyrobnychykh funktsii", Matematychni metody, modeli ta informatsiini tekhnolohii v ekonomitsi. Ekonomika i suspilstvo, vol. 4, 2016. [Online]. Available: http://www.economyandsociety.in.ua/journal/4_ukr/62.pdf Accessed on: July 8, 2019.

[4] Cobb-Douglas production function. [Online]. Available: https://en.wikipedia.org/wiki/Cobb\%E2\%80\%93Douglas_production function. Accessed on: July 10, 2019.

[5] I. M. Azam, A.Q. Khan \& B. Bakhtyar, "Surveying sources of economic growth: empirical evidence from Malaysia", Problems and Perspectives in Management, vol. 15(4), pp. 114-123, 2017. Doi: http://dx.doi.org/10.21511/ppm.15(4).2017.10

[6] A. M. Mapanga, O. Collins \& N. Mavetera, "Barriers to effective value chain management in developing countries: new insights from the cotton industrial value chain" Problems and Perspectives in Management, vol. 16(1), pp. 22-35, 2018. Doi: http://dx.doi.org/10.21511/ppm.16(1).2018.03.

[7] B. Penny, K. Fernandez-Stark, G. Gereffi, A. Guinn, "Connecting Local Producers in Developing Countries to Regional and Global Value Chains", OECD Trade Policy Papers, vol. 160, 2014. [Online]. Available: $\quad$ http://www.oecd.org/officialdocuments/ publicdisplaydocumentpdf/?cote=TAD/T/WP(2013)27/FINAL\&docL anguage=En. Accessed on: July 10, 2019.

[8] J. A. Al-Doori, "The impact of supply chain collaboration on performance in automotive industry: Empirical evidence", Journal of Industrial Engineering and Management JIEM, vol. 12(2), pp. 241253, 2019. Doi: https://doi.org/10.3926/jiem.2835

[9] E. V. Krikavsky's and Z. P. Vysotskaya "A chain cost of Porter (design, deconstruction, reconstruction) and managements behind values" Marketing and Innovation Management, vol .2, pp. 121-133. 2015. [Online]. Available: http://mmi.fem. sumdu.edu.ua/sites/default/files/mmi2015_2_121_133.pdf. Accessed on: July 10, 2019.

[10] A. Asaul, M. Voynarenko, L. Dzhulii, L .Yemchuk, L. Skorobohata, O. Mykoliuk, "The latest information systems in the enterprise management and trends in their development", Advanced computer information technologies (ACIT 2019) : 9th International Conference, Ceske Budejovice, Czech Republic, 2019, pp. 409-412. Available: https://easychair.org/conferences/overview?a=21185615.

[11] M. Voynarenko, K. Dumanska and N. Ponomaryova, "Formation of company's economic activity context in the strategic positioning process in emergent environment conditions", The 8th International Conference on Monitoring, Modeling \& Management of Emergent Economy, vol. 65, pp.1-7, Doi: https://doi.org/10.1051/shsconf/20196504005

[12] L.M. Karpenko, S. V. Filyppova, "Strategic competitive analysis of innovative enterprises development: predictive validity", Actual problems of economics, vol. 6(180), $2016 . \quad$ [Online]. Available: https://www.researchgate.net/publication/306208929_Strategic_competitive _analysis_of_innovative_enterprises_development_Predictive_validity Accessed on: July 1, 2019

[13] L. M. Karpenko, P.V. Voronzhak, "The system of analytical tools of integrated managerial analysis for the activation strategy of the enterprise innovative investment development the system", International Relations 2017: Current issues of world economy and politics: Conference proceedings 18th International Scientific Conference Smolenice Castle, Bratislava, 2017. [Online]. Available: https://fmv.euba.sk/www write/files/aktuality/2018/International Relations_2017_Current_issues_of_world_economy_and_politics.pdf Accessed on: July 1, 2019

[14] A. A. Melikhov, "Modeliuvannia innovatsiinoi skladovoi konkurentnoho rozvytku promyslovykh pidpryiemstv", Ekonomichnyi visnyk Donbasu, vol. $3(37), 2014.2$ [Online]. Available: http://nbuv.gov.ua/UJRN/ecvd_2014_3_24. Accessed on: July 1, 2019.

[15] M. V. Dykha, N. P. Tanasiienko \& G. M. Kolisnyk, "Ensuring of labor productivity growth in the context of investment and innovation activity intensificatio", Problems and Perspectives in Management, vol. 15(4), pp. 197-208, 2017. Doi: http://dx.doi.org/10.21511/ppm.15(4-1).2017.04.

[16] I. Strutynska, G. Kozbur, L. Dmytrotsa, O. Sorokivska, L. Melnyk, "Influence of Digital Technology on Roadmap Development for Digital Business Transformation", Advanced computer information technologies (ACIT 2019) : $9^{\text {th }}$ International Conference, Ceske Budejovice, Czech Republic, 2019, pp. 333-338. Available: https://easychair.org/conferences/overview?a $=21185615$.

[17] S. Ivasiev, M. Kasianchuk, I. Yakymenko, R. Shevchuk, M. Karpinski, O. Gomotiuk, "Effective Algorithms for Finding the Remainder of Multi-Digit Numbers", Advanced computer information technologies (ACIT 2019) : $9^{\text {th }}$ International Conference, Ceske Budejovice, Czech Republic, 2019, pp. 175-178. Available: https://easychair.org/conferences/overview? $\mathrm{a}=21185615$.

[18] L. M. Melnik, "Development of the system-integrated methodological approach to the assessment of the level of achievement of sustainable development of industrial enterprises on the basis of business indicators", Visnyk of the Odessa National University. Series: Economics, vol. 22(11), 2017. [Online]. Available: http://nbuv.gov.ua/UJRN/Vonu_econ_2017_22_11_29. Accessed on: July 8, 2019.

[19] L. V. Vaganova, I. I. Chaikovska, N. A. Khrushch, P. M. Hryhoruk, "Network structure as tool for developing information network economy", Financial and credit activity: problems of theory and practice, vol. .2, No 25, pp. 261-268, 2018. Doi: https://doi.org/10.18371/fcaptp.v2i25.136827

[20] V. Stadnyk, P. Izhevskiy, O. Zamazii, A. Goncharuk, O. Melnichuk "Factors of enterprises' strategic selection of participation forms in integration formations", Problems and Perspectives in Management, vol. 16, no.2, pp. 90-101, 2018. Doi: http://dx.doi.org/10.21511/ppm.16(2).2018.09

[21] O. Palyvoda, O. Karpenko, O. Bondarenko, S. Bonyar and A. Bikfalvi. "Influence of network organizational structures on innovation activity of industrial enterprises", Problems and Perspectives in Management, vol. 16(3), 2018. [Online]. Available: https:// www.researchgate.net/publication B26884133 Influence of network organizational structures on innovation activity_of_industrial_enterpris . Accessed on: July 10, 2019. 